\title{
Fenjiashu: Economic Development in the Chinese Countryside Based on Household Division Inventories, ca. 1750-1910
}

\author{
Meimei Wang and Bas van Leeuwen
}

\section{Introduction}

Economic development is usually researched from a macro perspective, i.e., measured by income-related measures such as GDP and explained by different factors such as labour, capital, with Total Factor Productivity (TFP) completing the explanation by capturing the remaining unexplained growth. Most of these macro-economic studies are based on (implicit) underlying micro-economic assumptions on how firms and households maximize profits as producers, and utility as consumers, within well-working markets. Yet, recent research in micro-economics has taught us that, i.a. bounded rationality, market failures, and irrational consumer preferences can exhibit a constraint on rational choices of consumers and producers (e.g. Schleifer 2000; Thaler 2015), in turn altering our view on many macro-economic studies. Therefore, in this paper, we seek to trace China's economic development ca. 1750-1910 by looking at micro behaviour of individual households as recorded in fenjiashu (household division documents). By doing so, we aim to gain an understanding about the pattern of household investment and the changes of family property size, both of which can be linked with the wealth creation capacity of each household.

There is a rich literature on explaining wealth creation of China from the perspective of household division, which can be separated into two branches. A first main branch of the literature deals with the impact of household division on the intergenerational accumulation of family property. The prevailing view is that the equal-male division in Chinese families meant downward social mobility and increasing poverty, due-according the theory-to the inevitable decline in family property size. Freedman (1979) found that it usually took several decades for the parents to accumulate family wealth, but after a household division it became partitioned into a number of smaller shares owned by different households. Therefore, Chinese families were trapped in a perpetual cycle of wealth accumulation and property fragmentation. 
This fragmentation arguably led to decreasing agricultural productivity. Liang (1990) argued that this equal division of household property limited the development of intensive large-scale production. Increasingly fragmented farms and smaller plot sizes for each household are usually considered to be the reasons agricultural production remained stagnant 'at-a-highlevel' for a long period (Zhang 1988; Myers 1999; Huang 2000; Zhao 2005). Yet, despite the declining amount of land per capita, the majority of households could still easily obtain a share of farmland. Some scholars (e.g. Flin 1981: 36-37; Seccombe 1992: 96-99; Houlbrooke 1984; 247; Foster 2002: 839-69) thus concluded that access to farmlands offered the possibility for most people to make a living in the agricultural sector, thereby discouraging migration out of rural areas. Consequently, not only did rural areas quickly increase in population density, but also a mobile labour class failed to form, both of which were crucial factors in the slow development of capitalist industrialization. This development also had positive economic effects, as the rural population increase combined with lack of mobility stimulated the development of non-agricultural industries in rural areas. ${ }^{1}$

Besides the above-mentioned traditional theory about the negative impact of the equalmale division in Chinese families on economic performance, in a second branch of the literature it is argued that agricultural fragmentation was in fact quite limited as some inheritance strategies were created to offset the negative effects of division. For example, Wakefield (1998: 202) found that wealthy Fujian families used educational trusts to foster education and examination success. Likewise, in Huizhou, merchant families used various strategies to protect their commercial capital over generations, such as splitting the capital rather than their business

\footnotetext{
${ }^{1}$ In addition, besides the direct impact on agricultural productivity, the decreasing family property size caused by the household division system was also argued to affect China's socio-economic development in various other ways. For example, after investigating 48 household division documents from Huizhou in the Qing Dynasty, Zhang (2010) found that, even though the equal-male division decreased the property scale of each household, the strength of the lineage was enhanced because of the accumulation of property excluded from the division and the spiritual cohesion resulting from these public properties. Likewise, Liang (1990) stressed that the household division strengthened the ideology about family in the Chinese mind, causing a different development path in China compared with that in the individual-oriented Western world. Man (1988), in turn, believed that the class structure characterized by the expansion of small farmers enhanced the long-term stability of despotism in China because there was no class rich and powerful enough to challenge the authority of the rulers.
} 
operations. Sometimes new households would take turns in running the family business, while in other cases one or several gifted branches were appointed to run the business, with other branches having the right to share in its benefits according to the share of capital supplied. This means that a positive effect of capital accumulation on economic growth remained possible.

The aforementioned studies, important though they are, are primarily based on scattered household division cases and theoretical deductions on how these affected the economy. Therefore, there is still only limited evidence either for or against the economic effect of the partial household division in China. In this paper, we begin Section 2 by providing a general description of the background to and basic allocation rules in fenjiashu documents. In Section 3 we focus on the goods most commonly reported in the documents and present general trends in property size for a number of household division documents collected from Zhejiang, Anhui, and Shanxi for the period ca. 1750s-1900s. We find evidence for wealth concentration up to ca. 1820 and a decline thereafter, rather than a long-term trend towards fragmentation. This finding is cross-checked against two sets of multiple, consecutive generations in the same large families, resulting in similar observations. The reduction found in fragmentation up to 1820 is consistent with two macro-economic theories on economic growth, dealt with in Section 4. The first theory argues that land concentration leads to economic growth, while the second theory argues that land concentration in a few hands leads to income inequality and, hence, to economic decline. Both theories are compared with consumption data from rare and detailed household division documents that include, in addition to the standard data on available land, rooms, and draught animals, also data on more mobile items such as clothes, antiques, and jewellery. These provide evidence of the living standard and its change over time in rural areas. We end with a brief conclusion.

\section{Inheritance Practices in Fenjiashu}

Household division (fenjia), a practice common among Chinese families, is, to a certain extent, comparable to probate inventories in Western countries (Schuurman 1980:19-33). In China, household division implied the splitting of one household into several while the property from the original family were divided among, and became private wealth of, the newly established families. This division was not restricted to rich households. It was widely accepted that 
household division documents were necessary to define property ownership clearly and avoid disputes in case there were any real estate such as rooms and/or land to be divided.

The structure of the household division documents was relatively standardized. At the time of the division of the household, there was usually a document created that was signed by the allocator, the successors, and several invited witnesses and guarantors. The basic information included in the document consisted of the direct cause and basic principle of the division (i.e. who obtained what share), the property inventory, the name of the persons involved, and the date. Sometimes, a brief history about the ups and downs of the family, the ancestors' sayings, or warnings passed on from generation to generation, were also mentioned in the document.

During recent years, an increasing number of fenjiash $u$ were discovered because an more and more scattered private documents and contracts were collected or even published as special collections. Especially, in Huizhou area of Anhui Province, Qingshuijiang region of Guizhou Province, Shicang area of Zhejiang Province, a large amount of well-kept private documents and contracts has been collected by historians and gradually compiled into large-scale multivolume archival collections. In some other places, such as Chengdu, Ningbo, Hubei, Yunnan, Fujian, and Taiwan, there are also private documents collections published although smaller in number. In addition, some research institutes and universities, for example the Chinese Academy of Social Sciences, also kept some private contracts in their libraries. Among these private documents, the majority concern land and house transaction contracts while household division contracts only account for a small share.

Given that we aim at discussing the development of capital based on household division documents, and given the available household division documents, we included data on the Lower Yangtze region (Zheijing and Anhui), which figures prominently in the Great Divergence debate, and Shanxi, which, because of its large group of Shanxi merchants, was considered one of the most important commercial force at that time. Our samples on Zhejiang cover all fenjiashu recorded in Collection of Civil Contracts from Shicang. For Anhui, we use all the samples available in Huizhou Qiannian Qiyue Wenshu: Qing and Republican China. In addition, we included several unpublished original fenjiashu from Anhui and Shanxi kept by the Institute of Economics and the Institute of Modern History of Chinese Academy of Social 
Sciences. Finally, several fenjiashu, taken from secondary literature, are also added to our database. This results in a dataset covering approximately 100 documents.

Before turning to the data, it is important to outline the inheritance practices in the household division documents. There exists a broad literature (Freedman 1979; Xing 1995; Wakefield 1998; Wang 2002; Zhen 2009) on when, why, and how family property was divided, based on studies of both fenjiashu and the judicial code on inheritance. Yet, in order to use this data for economic analysis, we need to be aware that household division in China had a number of unique characteristics when compared with typical Western customs.

First, we have to acknowledge that Chinese families considered remaining together for many generations as the preferred situation - even if, for various reasons, this often proved impossible. Hence, the main goal of household division was a sustainable development of the whole family. In the preface to the fenjiashu, there were usually one or several sentences added about the reasons for the division. Four reasons are frequently mentioned:

a) By ageing of the head and growth of the household, daily affairs became less easy to manage.

b) If a family grows, it is sometimes thought necessary to divide "like a tree that grows large and get branches".

c) Sometimes external economic circumstances played a role. In bad situations, brothers frequently wanted to remove their portions to avoid economic losses while the elder generation wanted to give them the opportunity to find their own way out.

d) Fear of a lazy and wasteful son.

It is important to stress that external economic factors also played a role (see point $\mathrm{c}$ ), which means the data are possibly biased towards households in bad economic circumstances. Yet, given that economic circumstances only make up a small part of the total number of reasons for the divide, and given that in this paper we do not aim to establish causality between the household division and economic growth, it will not affect our conclusion.

Unlike Western probate inventories, a split in Chinese families might occur at various stages of the life-cycle of a household, in order to avoid disputes, lower the management costs, and so on. For example, when several sons of a household got married and it became increasingly difficult for the parent(s) to maintain harmonious relations within the extended 
household, household division might take place while one, or both, of the parents were still alive. Even brothers, who had been living under the same roof for many years after both parents had passed away, could still split the household at any time to establish a new independent household. Moreover, a household division could occur multiple times among the same people - for example, farmlands were divided first, while rooms were distributed many years later or when the parents had accumulated new property after the last time a household division had taken place.

Second, there is also a difference from Western probates in the basic principle of the division. Howell (1978: 141-42) investigated 153 probates from Kibworth and Harcour since the $16^{\text {th }}$ century and found that in more than $80 \%$ of samples, all farmlands were inherited by the eldest son, while other sons obtained only sums of money. However, in China, equalpartition inheritance was the general rule. The basic idea was that household property should be divided equally among all sons. If there was a deceased son, usually his share would go to his widow and/or his next male generation. 'Pin da jun fen' ('the household property was divided into equal shares') was the most frequently used expression in fenjiashu, in order to stress the fairness of the division. It refers to equality not only in the quantity of items but also in the quality. Property was seldom divided absolutely equally, so the number of items and shares in each item allotted to each of the inheritors could vary; nevertheless, when quality was considered, the process was intended to result in a roughly equal division. For example, one large room might be equal to two smaller rooms. On account of more abundant sunshine, a room facing south might be as valuable as a room facing north plus an accessory such as a kitchen, a toilet, or a barn. Fertile farmland measuring $1 \mathrm{mu}$ near the home might be equivalent to $1.5 \mathrm{mu}$ of farmland of medium quality and at a further distance, or $1 \mathrm{mu}$ of farmland close to a water source might be equal to $2 m u$ of farmland on a mountain. Extra land could also be equal to two extra trees.

Of course, this does not necessarily mean absolute equality; perhaps 'fair' or 'equitable' would be more appropriate words. Many other factors were also usually taken into account. In most areas, those who made the greatest contribution to the family were given higher priority. For example, as Wakefield (1998: 200-202) noted, the eldest son and grandson might receive extra portions (to some extent because of their extra responsibilities in helping their parents to 
raise their younger siblings, or their duties in ancestor worship, and so on). If a sibling remained unmarried at the time of the division, sometimes he or she was entitled to marriage expenses (in the case of a son) or a dowry (in the case of a daughter). In addition, at household division time, it was a normal practice to exclude some property (yangshan property) from the division process, for use in the continued support of the daily expenditures of the living parent(s), or in corporate property, or in a trust, or as public set-aside for a specific purpose. Equal division, often conducted by drawing lots, occurred only after the extraction of these various set-asides, but all such special arrangements were not mandatory. Different dividers might favour different considerations, and the prevailing customs might also vary across regions. Some undivided properties might be split into shares when the next household division occurred. For instance, yangshan property for the living parent(s) might, according to the parent will(s), become jitian (public set-asides to cover the public expenses of ceremonial activities), become equally divided among all sons, or be left for the son who made the greatest contribution to taking care of the parents.

A third difference from Western probates was the way property was recorded. The main body of the fenjiashu consists of the inventories of all major properties of the original family and the arrangement of these properties; however, usually only real estate such as farmlands and rooms were recorded and described in detail. Farmlands were often described both in terms of location and, if there were any, the names of tenants. The quantity of farmlands was usually recorded in terms of the unit of rent (measured in unhusked rice), or plot, or $m u$. Housing was often described in terms of location and the number of rooms, while its size was rarely described. In addition, if there were any such items, then an in-house shop, money-lending business, or shares in a family business should also be recorded. Farm tools, draught animals, and trees were sometimes included. Mobile items such as furniture, clothes, and utensils were usually mentioned as a single item in the fenjiashu, as 'combined together and divided into shares for each heir equally'. Only a very small number of fenjiashu include detailed inventories with such kinds of mobile items recorded separately (see Section 4). All recorded property was listed share by share; and in each share, all items were listed by category.

\section{Changes of Family Property Size over Generations in Fenjiashu}


Under an impartible inheritance system, the eldest son receives almost all of the household property. Hence, family property accumulated by the older generation was completely inherited by a single new household. Never being divided, the family property size and the corresponding production scale was maintained before and after the division. However, in China, partible inheritance was the standard practice. No matter what the exact size was, a single property was split into several smaller portions. For each new household, the total amount of property was less when compared with that of the original family; however, we cannot conclude $a$ priori that this meant a decrease in household property size and, as proposed in some studies (see Section 1), a consequently lower productivity and increased poverty. In this section, we therefore start by investigating whether farm sizes indeed declined over time, using a set of documents from Zhejiang, Anhui, and Shanxi. Since the observed trend may be caused by biases in the choice of families, or by different local inheritance practices, we compare these results with the fenjiash $u$ created by several consecutive generations within the same families, in order to analyse the influence of partible division on overall trends in farm sizes.

The most frequently used evidence for scholars to support their view on the negative impact of household division on family property size is the scattered farmland ownership. In other words, contrary to the concentration of farmland ownership, which was considered a necessary condition for large-scale agricultural production, technological evolution, and the creation of the modern capitalist mode of production, the vast majority of farmland in China consisted of small plots in the hands of smallholders. According to Luo and Jing's (1985: 16076) investigation into 28,029 rural households in 197 villages from 42 counties in Shandong around 1897, 56.3\% of the households were small land-holding peasants. Families owning enough farmland to be classified as landlords accounted for only $2.97 \%$. Within the landlord class, $56.48 \%$ of households owned farms consisting of less than $500 \mathrm{mu}$, mostly 150-300 mu (equivalent to approximately $25-50$ acres), the usual farm size of a self-employed farmer in contemporary Britain. Dai (1980: 346-48) found that in Huolu County of Zhili Province in $1725-1750$, only $22.6 \%$ of farmlands were owned by wealthy households owning more than $100 \mathrm{mu}$. The average size was only $15 \mathrm{mu}$ per household. Huang (2000: 107) made a further calculation that among those families owning more than $100 \mathrm{mu}, 65 \%$ had no more than 200 $m u$. In another study, Huang (1992: 336) analysed 8 villages in lower Yangtze Region for the 
period 1930-1940s and likewise arrived at the conclusion that peasant families running fragmented plots of land were predominant. After investigating 16,000 peasant households in 22 provinces, Buck (1937: 181-85) argued that one of the most important characteristics of China's agricultural production was the fragmentation of farmland. He found that, on average, each peasant household had 5.6 plots of land, with an average size of around 0.79 acres in riceproducing and 1.16 acres in wheat-producing area per plot. Moreover, the average distance between each plot for the same household was around 0.3-0.5 miles. Fei (1986: 136-37) found the same phenomenon in Wujiang County, Jiangsu Province. In his field study in the 1930s, he found each family owning several scattered pieces of farmland, and the distance between two scattered plots could be as far as 20 minutes by boat. He believed that the extra time involved in going back and forth between scattered plots reduced productivity, and the small size of each plot limited the space to take advantage of animal power.

All these studies show that the farms were highly fragmented, and there were rarely landlords on a large scale; this, according to the studies, resulted in a stagnant peasant economy. Our statistics, based on fenjiashu, are consistent with the observation that the share of land per landowner is small; nevertheless, we disagree with the popular explanation of the fragmentation of land proposed by many scholars (e.g. Fei 1986; Huang 2000)—-the explanation that this fragmentation directly followed from the frequent division occurring through the inheritance process.

We plotted, from our entire sample of fenjiashu, the amount of farmland held by each household that was divided at the time of division (Figure 1). It is clear that, measured in terms of the rent, usually the farm size of an individual household was in the range 10,000-30,000 jin of unhusked rice. Based on Cao's estimate (2015) that the usual rent of $1 \mathrm{mu}$ was approximately 1.4-1.6 dan (i.e. 182-208 jin) in Anhui before the late Qing dynasty, and combined with our findings in a number of fenjiash $u$ in which both the dan and $m u$ were mentioned, the observed farm size of individual households is concentrated between 50 and $150 \mathrm{mu}$. 
Figure 1. Household Farmland (in jin income in unhusked rice) as Recorded in Fenjiashu

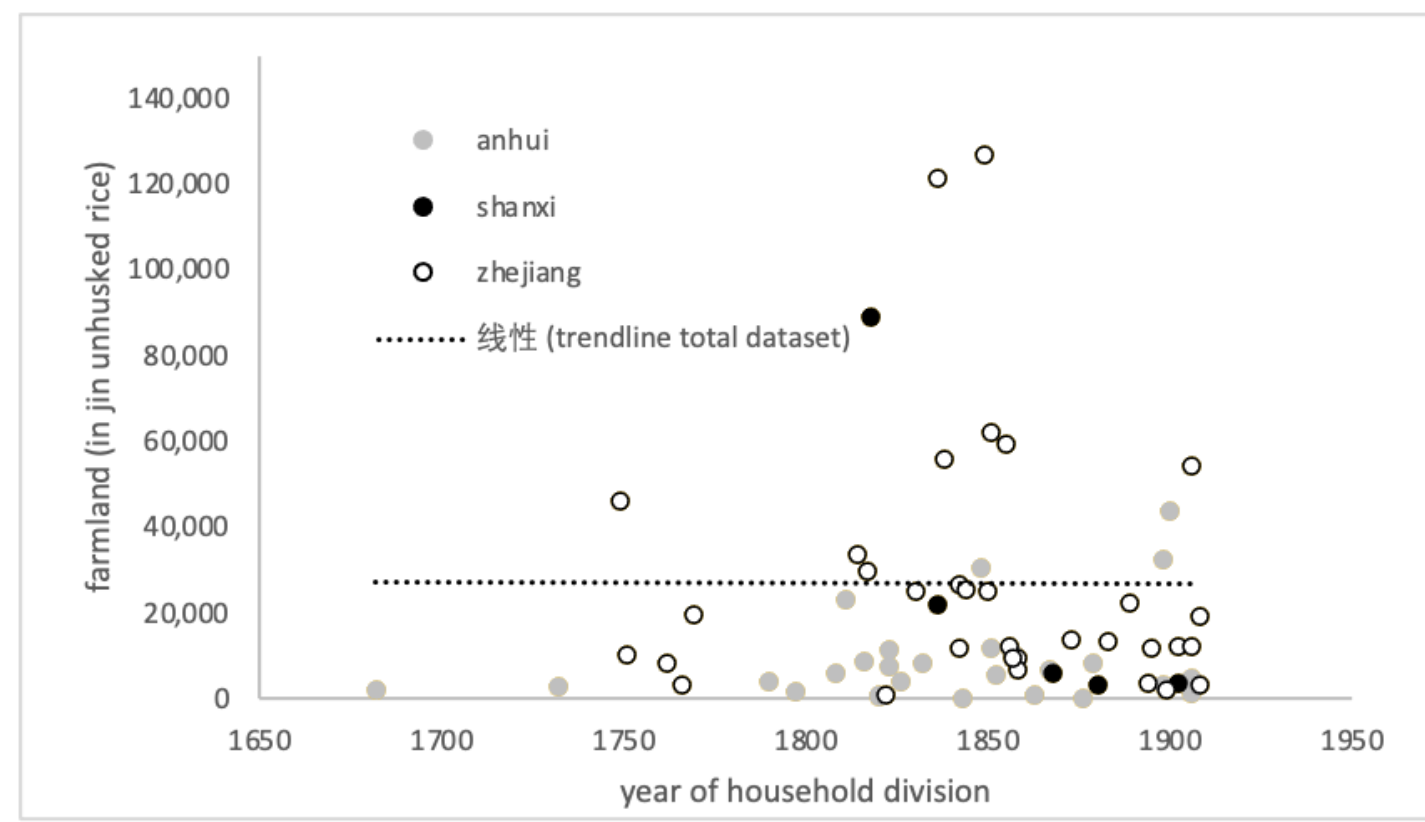

Source: all collected Fenjiashu

Figure 1 thus confirms the widely accepted view that the farm size of most landowners was small. Yet, even though small landowners were predominant, we do not find a general decline in farm sizes over time. In fact, many of the above-mentioned studies claiming that farmland fragmentation took place found evidence only of the existence of small farm sizes at a specific point in time, but they did not show that it changed over time. Hence, we do not think there is sufficient evidence to argue that household division is an important explanatory factor for the low household property sizes. On the contrary, we can see both increases and decreases in the sizes of farmland owned by each family, with a peak around 1800-1850.

In order to understand the effect of household division on land fragmentation, we have to take a more detailed look at household dynamics. As mentioned, the division of farmlands and rooms is the main topic in fenjiashu, whereas other items were seldom described in detail. However, given their importance, the amount of farmland and the number of rooms can be used to represent the property scale of every household to a large extent. Hence, here we calculate only the amount of farmland and number of rooms. Yet, even this is not always straightforward. We sum up the amount of farmland and number of rooms recorded in the fenjiashu (both equal 
shares for all sons or brothers and set-asides are included) as the amount of property accumulated by the older generation. If there were multiple times of division, we add them together and get the total amount of household property accumulated by the older generation at the last division time. By doing so, the average amount of property of the older generation can be considered to be the starting level of the next generation. When we compare these numbers with the property scale inherited by the third generation, we can determine the amount of property created by the second generation, and so forth. This requires fenjiashu created by several consecutive generations of the same lineage. Among all collected fenjiashu for this paper, there are only 2 lineages with consecutive household division records.

The first one is a common lineage of the Que family from Shicang, Zhejiang province. We obtained these household division documents from different volumes of Shicang Qiyue (edited by Cao Shuji 2015). Here we have to note that in these fenjiashu the amount of farmland was sometimes calculated based on its acreage in the units of $m u$, but in most cases it was calculated by the rent (paid in unhusked rice). However, as $m u$ measures the physical size of the plots of farmlands rather than reflecting the value of the farmland due to the differences in quality, for this paper the rent (expressed in unhusked rice) is preferred. ${ }^{2}$

\footnotetext{
2 The main traditional unit for expressing the volume of unhusked rice was the dan. In Shicang, 1 $d a n=2$ luo $=8$ tong. To facilitate our study, we convert the traditional unit of volume to the modern unit of weight, i.e. jin ( 1 jin=500 grams). According to Shi Zhihong's study (2018: xxii), to measure the weight of rice, 1 dan=130 jin.
} 
Figure 2. Mean Household Farmland (in jin income unhusked rice) and number of rooms by Generation of the Que Family from Zhejiang

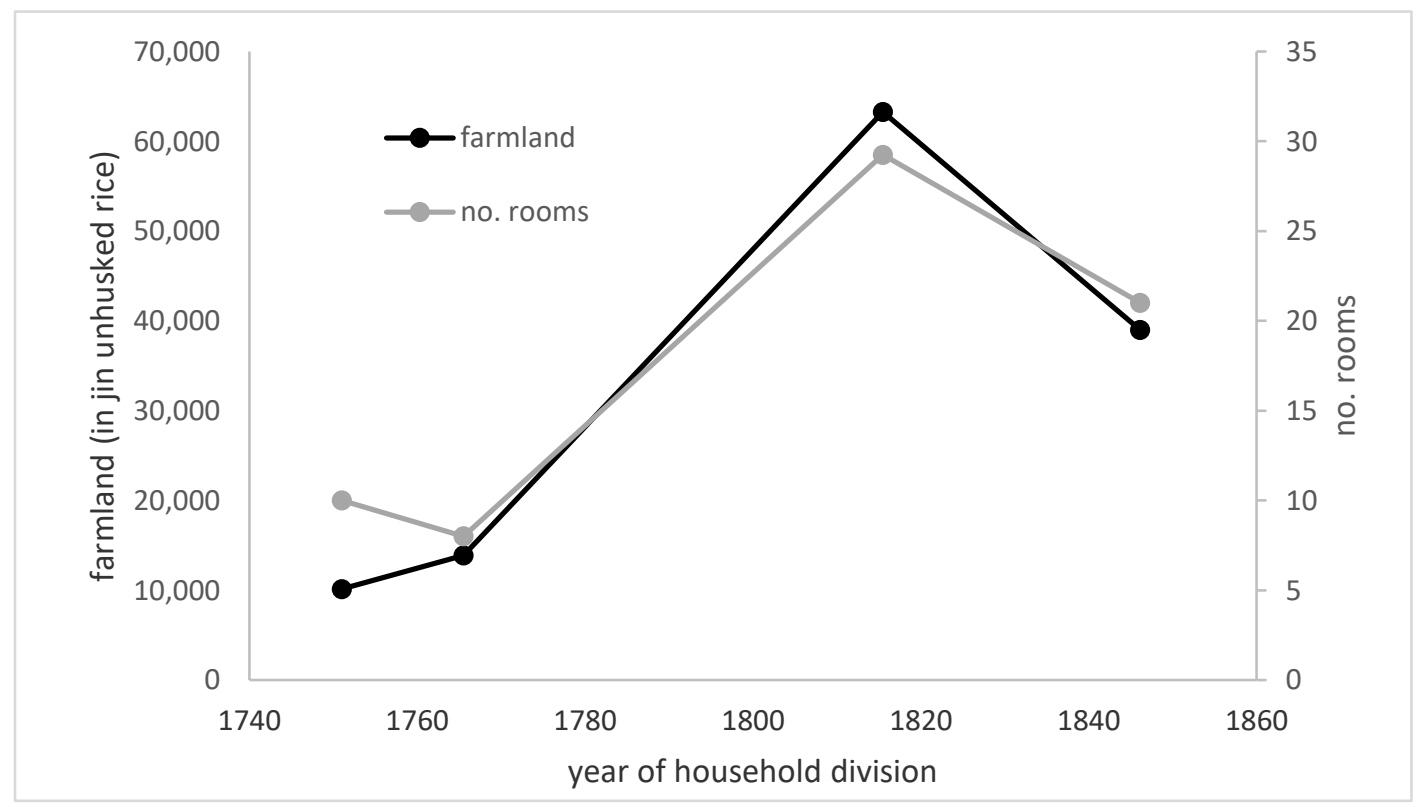

Source: Cao Shuji et al. (eds), 2015, Collection of Civil Contracts from Shicang (石仓契约), Zhejiang University Press, vol. 8, issue 4; vol. 7, issue 4; vol. 6, issue 4; vol. 5, issue 4; vol. 5, issue 3.

Based on records of the property preserved by each generation of this lineage, we plot the mean household farmland of each generation of the Que family (Figure 2). There was a remarkable increase in the mean size of household property in the period 1750s-1820s. Que Shengzong left 10,140 (jin of rice) farmland and 10 rooms for his three sons. Each son started with about 3,380 jin farmland and 3.3 rooms but accumulated much more property up to their final life stage. Que Qichun had 19,565 (jin of rice) farmland and 9 rooms, while Que Qixing had 8,242 (jin of rice) farmland and 7 rooms, while the third son remained unreported. The upward trend was continued during the following generation, and the size of mean household property expanded rapidly. Que Qixing had four sons: Tianyou, Tianpei, Tiangui, and Tiankai. Each son inherited about 2,060.5 (jin of rice) farmland and 1.75 rooms. After several decades, Tianyou left 29,848 (jin of rice) farmland and 24 rooms to his heirs. Tianpei had 33,540 (jin of rice) farmland and 56 rooms to be inherited. Tiankai accumulated a total of 121,290 (jin of rice) farmland and 34 rooms, and Tiangui possessed 68,387 (jin of rice) farmland and 12 rooms. The property size of each son far exceeded that of their older generation. Thus, during these 
consecutive generations, everyone successfully made his own progress based on what he had inherited from the older generation.

This trend of increasing wealth for each generation for the Que family was interrupted after 1800 , when a decline began that continued over the $19^{\text {th }}$ century. That this trend is not an artefact of the choice of data is clear from a comparison with our complete dataset in Figure 1, which shows a similar inverted u-curve for Zhejiang province where the Que family resided. Alternatively, we can compare it with the mean wealth of the other sample Ye family from Anhui, which exhibits the same up- and downward trend as that of the Que family from Zhejiang, and the same general pattern as our dataset on Anhui province given in Figure 1, with a peak in wealth around the 1820s-1830s (Figure 3).

Figure 3. Mean Household Farmland (in $m u$ ) and number of rooms by Generation of the Ye Family from Anhui



Source: Fenjiashu from Ye Family in 1790, 1831, 1851, 1852, 1863, 1820, unpublished sources.

Our findings of the increasing $18^{\text {th }}$-century farm size are consistent with some other studies. For example, Perkins (1969: 128-31) claimed that the proportion of landless labourers/tenants changed around the mid- $19^{\text {th }}$ century from a rise to a decline, thus suggesting rising farm sizes until 1850 and declines afterwards. A similar observation is made by Shi (2018, appendix D), 
who claimed that 'from the mid-Qing onward, with the development of land annexation and concentration, owner-peasants reduced continuously'.

In addition to finding an inverse u-shaped trend in land concentration, we can also make a further five observations about the data:

First, inequality among branches of the same family was substantial. As mentioned before, based on the basic principle of fair division, the eldest son sometimes obtained an extra portion at division time; however, the history of the Que family shows that, for the main branch led by the eldest son, this did not necessarily result in the best wealth accumulation (see Table 1). It is clear that the main branch usually had a smaller land size than the average amount of land among all households of that generation, despite their initial extra portion obtained after the household division. This means that, in general, the main branch was disadvantaged. To some extent, this might be caused by extra responsibilities shouldered by the eldest son towards the whole family compared to his brothers. Usually, the eldest son had to help his parents to raise the younger siblings, so that often he would have to give up opportunities beneficial to his own development — for example, he might drop out of school earlier. In addition, because an eldest son carried the burden of the whole family at too young an age to make his own independent choices, he usually followed his parents' arrangement which might not be optimal to develop his own talents and personal interests. Consequently, with path dependence gradually forming, his life path was more likely to be influenced by his older generation and his space for exploration and creation would be more limited. All these factors might cause negative effects on the development of the eldest son and his main branch. 
Table 1. Comparison of Household Farmland for Main Branch and Mean Household Farmland (in jin income unhusked rice) by Generation + Inequality of the Que Family (Zhejiang)

\begin{tabular}{cccccc}
\hline \hline $\begin{array}{c}\text { Approximate } \\
\text { Year Split }\end{array}$ & $\begin{array}{c}\text { Gener } \\
\text { ation }\end{array}$ & Branch & & & \\
& & $\begin{array}{l}\text { Main } \\
\text { Branch }\end{array}$ & $\begin{array}{c}\text { Mean } \\
\text { Generatio } \\
\mathrm{n}\end{array}$ & $\begin{array}{c}\text { Standard } \\
\text { Deviation } \\
\text { Generation }\end{array}$ & $\begin{array}{c}\text { Coefficient of } \\
\text { Variation Generation }\end{array}$ \\
\hline 1751 & 1 & 10,140 & 10,140 & n.a. & n.a. \\
1766 & 2 & & 13,904 & 8,007 & 0.6 \\
1816 & 3 & 29,848 & 63,266 & 42,400 & 0.7 \\
1846 & 4 & 24,984 & 38,974 & 21,874 & 0.6 \\
1877 & 5 & 12,350 & 11,836 & 5,813 & 0.5 \\
1898 & 6 & 1,940 & 8,893 & 7,382 & 0.8 \\
\hline
\end{tabular}

Note: Due to the lack of data about the situation of the main branch starting from the first generation, the main branch in the above table was initiated from the youngest son of the first generation.

Source: Cao Shuji et al. (eds), 2015, Collection of Civil Contracts from Shicang (石仓契约), Zhejiang University Press, vol. 8, issue 4; vol. 7, issue 4; vol. 6, issue 4; vol. 5, issue 4; vol. 5, issue 3.

Second, inequality existed not only for the main branch of the family; the high coefficient of variation within each generation (see Table 1) also reminds us of the large gap between other branches. Based on the same initial property size, some new households became much richer while there were also others which became poorer. Therefore, the difference in property size among different branches was primarily caused by the capacity of the members in each new household and the number of sons. To take a simple example: person A had 90 units of farmland and three sons: B, C, and D. Regardless of whether the three sons decided to divide the household or not, each of them enjoyed only the benefits brought by 30 units of farmland. Therefore, the household property size for each son did not change from before to after the division. The gap formed only gradually after the division, based on the individual sons' different performances. After several decades, B had 90 units of farmland and two sons - that is, the property size had tripled while the population had doubled. In this situation, each of his sons could enjoy 45 units of farmlands, which is more than the 30 units their father had obtained at household division. 
Third, an often-mentioned factor in favour of wealth accumulation is that one family cultivating 90 units of farmland before the household division would be more efficient than each son having 30 units of farmland, because a smaller farm size led to a change in production mode. But according to the records in the fenjiashu, in most cases the farm tools and animals were excepted from the division, since they were considered a public means of production. Moreover, due to partial division of rooms, the residences of all sons were close to each other. These two factors facilitated, to a large extent, the cooperation of the three sons in cultivating the 90 units of farmlands, with shared farm tools and animals after the division. For this reason, household division did not inevitably result in scattered production.

Fourth, from the fenjiashu, we can observe that the divided farmland had been originally fragmented. It is also from the fenjiashu, combined with extant land trade contracts and family real estate purchasing records, that we find that for most families, farmlands were bought little by little. The accumulation of farmland was a long march for ordinary families, as it was difficult for them to save enough money to buy a large piece of farmland. When they had accumulated a certain amount of savings over a period of years, they might buy a small plot. On the sellers' side, farmlands were sold as a consequence of financial difficulties. If sellers could get enough money to escape from their current difficulties, they were unwilling to sell the whole of a large piece of farmland, so the most common practice was to sell a small portion. Therefore, we can conclude that the fragmentation of farmlands was more likely to occur during these land trade processes, rather than just from household divisions.

Fifth, it is also important to mention that partible inheritance did not conflict with the possibility that one might want to go to urban areas to look for opportunities in other industries, similar to what occurred under the impartible Western inheritance system. In our collected fenjiashu, we found two sons of the Zhang family at the time of household division asking for 1,000 liang of money instead of farmland and rooms, because they did not want to remain in the agricultural sector.

All in all, we find accumulation of landed wealth up to ca. 1820, and it is evident that household division did not necessarily lead to a decline in household property size. However, for a more rounded picture of the relation between household property and economic growth, in Section 4 we will look at consumption and wealth patterns. 


\section{Consumption and Wealth in Fenjiashu}

From the foregoing, the main conclusion is that the partial inheritance system not necessarily led to increasing fragmentation of household wealth. Hence, This implies that the theory that the partial inheritance system led to continues declining per capita output does not hold. Yet, there are two views one how macro-economic growth is consistent with first rising, and later declining, farm sizes. First, one could argue that the peak in land concentration around 1820 (noted in Section 3) was also a peak in the real economy. Indeed, many economic historians believed that there was a depression in China (the so-called Daoguang depression) in the 1820s1830s (Wu 2001:241; Maddison 1998: 40-41), which might have caused the subsequent decline both in GDP per capita and land concentration. This point of view is seemingly confirmed within the Great Divergence debate, by the California school, which claimed that China grew in per capita GDP until the late $18^{\text {th }}$, or even the start of the $19^{\text {th }}$ century. Hence, the peak in household wealth corresponds with the peak in the real economy.

A second view is that the peak in household wealth corresponds to a decline in the real economy. The most persuasive evidence for this view comes primarily from analyses of urbanization and GDP per capita. Xu et al. (2018: 368, 393, 322-68) found GDP per capita declined until the start of the $19^{\text {th }}$ century and stagnated thereafter. Likewise, urbanization continued to decrease before 1800 and became stagnant after 1800 . The data also show little rural-urban migration before the 1820 s, due to the development of rural handicraft industries such as mining, metallurgy, tea-making, and textiles. This development meant that even peasants who did not have much farmland could easily find other part-time job opportunities to raise their household income. However, in the meantime, the rural population expanded more rapidly than the urban population, which meant a larger proportion of people becoming locked in the countryside (Cao 2001; 707).

We can test both theories by looking at consumption data, being a proxy for economic growth, from fenjiashu, because, in addition to houses and farmlands, some detailed household division inventories offer a rough impression of the standard household items such as furniture, utensils, and garments that were usually owned by typical families. 
Of course, as pointed out in Section 2, fenjiashu present a significant challenge to historians: we cannot be certain that the inventories include all the property present in the household. There might be household divisions occurring multiple times within a single generation, or some families might just consider it unnecessary to record all items. Despite such limitations, we can still make a comparison among these scattered household division documents to gain a rough picture of consumption trends. If we find that the quantity of important items or valuables being paid specific attention at the time of household division increased over time, it is a reasonable assumption that the consumption increased, even though we do not know the exact composition of household items.

Table 2. Mean Numbers of Household Items by Household Recorded in Fenjiashu

\begin{tabular}{|c|c|c|c|c|c|}
\hline Year & Utensils & Furniture & $\begin{array}{c}\text { Cloths and } \\
\text { Textiles }\end{array}$ & $\begin{array}{c}\text { Ornament and } \\
\text { Antiques }\end{array}$ & Farmland \\
\hline $\begin{array}{l}1732- \\
1790\end{array}$ & 71 & 8 & 4 & 8 & $15,325.0$ \\
\hline $\begin{array}{l}1791- \\
1820\end{array}$ & 105 & 15 & 5 & 13 & $31,694.0$ \\
\hline $\begin{array}{l}1821- \\
1850\end{array}$ & 84 & 14 & 10 & 10 & $26,234.8$ \\
\hline $\begin{array}{l}1851- \\
1890\end{array}$ & 20 & 7 & & 7 & $11,674.8$ \\
\hline $\begin{array}{l}1891- \\
1910\end{array}$ & 17 & 6 & 5 & & $33,020.0$ \\
\hline
\end{tabular}

Source: calculated based on all collected fenjiashu

We classify all consumption items listed in each fenjiashu with detailed inventories into four categories and list their mean numbers in each period in Table 2. We find an obvious peak of consumption around the period 1790-1850s. If we compare the consumption with the farm size, it is clear that there was a positive relation between the amount of capital (family property) and consumption during the period 1732-1890. When the farm size increased in the period 1791-1820, the consumption also increased, even though at a much slower speed. In other words, the consumption lagged behind the expanding property size. In the following three decades, consumption, together with farmland size, went down slightly. 
Finnane (2017: 163-86) and Wu Jen-shu and Wang Dagang (2017: 196-203) found, for urban areas, a similar phenomenon: the consumption in some categories increased despite economic hardship. Finnane found the consumption of luxury goods in Yangzhou to be at its highest level during the $18^{\text {th }}-19^{\text {th }}$ centuries, because of new and attractive goods entering the market and a flourishing culture of consumption even in the city. Similarly, Wu Jen-shu and Wang Dagang found the consumption of clothing in Ba County increasing in the $18^{\text {th }}$ century, due to the variety in styles and materials and the expanding range of products available and brought by international trade and domestic production. In the case of our, predominantly agricultural, fenjiashu we can imagine people were increasingly willing to spend resources on appearances. Owing to the expanding supply (including imported goods), the price of clothing declined; combined with increasing and changing styles, increasing consumption of clothing and textiles would be a good choice to raise the level of one's public display. Compared with ornaments, antiques, and utensils, furniture was also a more effective and visible option to improve one's appearances.

If we look into the composition of all these household items during the period 1791-1850, in the category of ornament and antiques and utensils, we can find more articles made of jade, glass, copper, brass, and leather, and more home decorations such as scrolls with calligraphy and even dressing mirrors appearing in the inventories of common households. As regards furniture, we find more styles and variety, and items such as lacquer trays, footrests, painted hat-stands, teapots, and hat boxes. The styles and materials of garments, such as robes and satin skirts with embroidery, also increased.

However, the flourishing rural consumption did not last long. Along with the further decline in farm size between 1851 and 1890, the consumption shrank. In the period 1891-1910, despite the recovery of farm sizes, due to the decline in population, the consumption was even less than it had been in the early $18^{\text {th }}$ century. This means that people did not grow richer.

Our findings thus provide a mixed picture. Supporting the view that rising farm sizes correspond with rising per capita income, we find evidence that, even with increased fragmentation, brothers often remained working together thus increasing efficiency (see Section 3). This is confirmed by the use of consumption goods, which increased during periods with less fragmentation and declined afterwards. However, supporting the view that land 
concentration led to increased inequality and economic decline, we find that inequality indeed increased strongly (see Table 2). There is an alternative way of dealing with this based on, for example, Williamson (2000). We can divide utensils (being relevant to both rich and poor households) by GDP per capita (Xu et al. 2017) to get an index of inequality. With more utensils capturing a small class of richer households, and GDP per capita capturing mean income, a rise in this index implies rising inequality. Indeed, the index of 100 in 1750 increases to ca. 200 in the period 1800-1840, then declines to ca. 90 after 1860, thus suggesting that the boom in land size around 1820 was at least partially caused by increased rural inequality.

\section{Conclusion}

Probate inventories have gained much attention over the past decades. This is much less the case for their Chinese equivalent in fenjiashu. Nevertheless, the literature that does exist points to declining farm sizes due to equal-share inheritance. This declining farm size, in turn, is often argued to lead to lower economic productivity. By analysing household division documents from Zhejiang, Anhui, and Shanxi for the period 1750s-1900s, we explored the changes in household property size over time and the impact of equal household division on the accumulation of household property.

Contrary to much of the existing literature, we found that household property size peaked around the period 1800-1830s, suggesting that the equal-share system did not necessarily lead to land fragmentation. This is confirmed when we look at the property size of several consecutive generations from the same large family, which resulted in the same inverted ucurve of property size by household over time.

This increase, and subsequent decrease, mean that farm size is compatible with various theories of macro-economic development: first, increasing farm size means higher output; and second, increasing farm size leads to more rural inequality - and, consequently, to lower per capita income. Comparing the farm size trends with the available detailed fenjiashu, we find increasing consumption going hand in hand with rising farm sizes. Notable too is the increasing variety of styles and materials in consumption. On the other hand, with luxury consumption being strongly related to farm size, inequality increased; indeed, the index derived by dividing utensils by GDP, as a measure of inequality, shows a peak in rural inequality around 1820 . 
Appendix 1 Household Property of several consecutive generations of the Que Family

\begin{tabular}{|c|l|c|c|c|c|c|c|}
\hline $\begin{array}{c}\text { Number of } \\
\text { Generation }\end{array}$ & Name & Year & $\begin{array}{c}\text { Farmland } \\
\text { (jin } \\
\text { unhusked } \\
\text { rice) }\end{array}$ & Rooms & $\begin{array}{c}\text { Number } \\
\text { of sons }\end{array}$ & $\begin{array}{c}\text { Average } \\
\text { Farmland } \\
\text { (jin } \\
\text { unhusked } \\
\text { rice) }\end{array}$ & $\begin{array}{c}\text { Average } \\
\text { Number } \\
\text { of } \\
\text { Rooms }\end{array}$ \\
\hline 1 & Que Shengzong & 1751 & 10140 & 10 & 3 & 3380 & 3.3 \\
\hline 2 & Que Qichun & 1769 & 19565 & 9 & 3 & 6521.67 & 3 \\
\hline 3 & Que Sanyou & & & & & & 3 \\
\hline 4 & Que Decong & 1844 & 1924 & 6 & 2 & 962 & 3 \\
\hline 5 & Que Hanwei & 1873 & & 2 & 2 & & 1.2 \\
\hline 6 & Que Yuding & 1894 & 3250 & 6 & 5 & 650 & 3 \\
\hline
\end{tabular}

\begin{tabular}{|c|l|c|c|c|c|c|c|}
\hline $\begin{array}{c}\text { Number of } \\
\text { Generation }\end{array}$ & Name & Year & $\begin{array}{c}\text { Farmland } \\
\text { (jin } \\
\text { unhusked } \\
\text { rice) }\end{array}$ & Rooms & $\begin{array}{c}\text { Number } \\
\text { of Sons }\end{array}$ & $\begin{array}{c}\text { Average } \\
\text { Farmland } \\
\text { (jin } \\
\text { unhusked } \\
\text { rice) }\end{array}$ & $\begin{array}{c}\text { Average } \\
\text { Number } \\
\text { of } \\
\text { Rooms }\end{array}$ \\
\hline 1 & Que Shengzong & 1751 & 10140 & 10 & 3 & 3380 & 3.3 \\
\hline 2 & Que Qixing & 1762 & 8242 & 7 & 4 & 2060.5 & 1.75 \\
\hline 3 & Que Tianyou & 1817 & 29848 & 24 & 4 & 7462 & 6 \\
\hline 4 & Que Depei & 1855 & 24984 & 22 & 2 & 12447 & 11 \\
\hline 5 & Que Hanxiang & 1856 & 12350 & 20 & 5 & 2470 & 4 \\
\hline 6 & Que Yushu & 1899 & 1940 & 4 & 3 & 646.66 & 1.33 \\
\hline
\end{tabular}

\begin{tabular}{|c|l|c|c|c|c|c|c|}
\hline $\begin{array}{c}\text { Number of } \\
\text { Generation }\end{array}$ & Name & Year & $\begin{array}{c}\text { Farmland } \\
\text { (jin } \\
\text { unhusked } \\
\text { rice) }\end{array}$ & Rooms & $\begin{array}{c}\text { Number } \\
\text { of sons }\end{array}$ & $\begin{array}{c}\text { Average } \\
\text { Farmland } \\
\text { (jin } \\
\text { unhusked } \\
\text { rice) }\end{array}$ & $\begin{array}{c}\text { Average } \\
\text { Number } \\
\text { of } \\
\text { Rooms }\end{array}$ \\
\hline 1 & Que Shengzong & 1751 & 10140 & 10 & 3 & 3380 & 3.3 \\
\hline 2 & Que Qixing & 1762 & 8242 & 7 & 4 & 2060.5 & 1.75 \\
\hline 3 & Que Tianyou & 1817 & 29848 & 24 & 4 & 7462 & 6 \\
\hline 4 & Que Dewei & 1842 & 26430 & 16 & 2 & 13215 & 8 \\
\hline 5 & Que Hanwen & 1842 & 11700 & 20 & 4 & 2925 & 5 \\
\hline 6 & Que Yuting & 1895 & 16601 & 22 & 4 & 4150.25 & 5.5 \\
\hline
\end{tabular}

\begin{tabular}{|l|l|l|c|c|c|c|c|}
\hline $\begin{array}{l}\text { Number of } \\
\text { Generation }\end{array}$ & Name & Year & $\begin{array}{c}\text { Farmland } \\
\text { (jin } \\
\text { unhusked } \\
\text { rice) }\end{array}$ & Rooms & $\begin{array}{c}\text { Number } \\
\text { of Sons }\end{array}$ & $\begin{array}{c}\text { Average } \\
\text { Farmland }\end{array}$ & $\begin{array}{c}\text { Average } \\
\text { Number } \\
\text { of } \\
\text { Rooms }\end{array}$ \\
\hline
\end{tabular}




\begin{tabular}{|c|l|l|c|c|c|c|c|}
\hline & & & & & & $\begin{array}{c}\text { (jin } \\
\text { unhusked } \\
\text { rice) }\end{array}$ & \\
\hline 1 & Que Shengzong & 1751 & 10140 & 10 & 3 & 3380 & 3.3 \\
\hline 2 & Que Qixing & 1762 & 8242 & 7 & 4 & 2060.5 & 1.75 \\
\hline 3 & Que Tianpei & 1814 & 33540 & 56 & 4 & 8385 & 14 \\
\hline 4 & Que Defu & 1855 & 59163 & 22 & 3 & 19721 & 7.33 \\
\hline 5 & Que Hanli & 1908 & 19240 & 7 & 2 & 9620 & 3.5 \\
\hline
\end{tabular}

\begin{tabular}{|c|l|c|c|c|c|c|c|}
\hline $\begin{array}{c}\text { Number of } \\
\text { Generation }\end{array}$ & Name & Year & $\begin{array}{c}\text { Farmland } \\
\text { (jin } \\
\text { unhusked } \\
\text { rice) }\end{array}$ & Rooms & $\begin{array}{c}\text { Number } \\
\text { of Sons }\end{array}$ & $\begin{array}{c}\text { Average } \\
\text { Farmland } \\
\text { (jin } \\
\text { unhusked } \\
\text { rice) }\end{array}$ & $\begin{array}{c}\text { Average } \\
\text { Number } \\
\text { of } \\
\text { Rooms }\end{array}$ \\
\hline 1 & Que Shengzong & 1751 & 10140 & 10 & 3 & 3380 & 3.3 \\
\hline 2 & Que Qixing & 1762 & 8242 & 7 & 4 & 2060.5 & 1.75 \\
\hline 3 & Que Tiankai & 1817 & 121290 & 25 & 3 & 40430 & 8.33 \\
\hline 4 & Que Dezhao & 1850 & 60957 & 32 & 4 & 15239.25 & 8 \\
\hline 5 & Que Hanrong & 1886 & 13780 & 9 & 3 & 4593.33 & 3 \\
\hline
\end{tabular}

\begin{tabular}{|c|l|c|c|c|c|c|c|}
\hline $\begin{array}{c}\text { Number of } \\
\text { Generation }\end{array}$ & Name & Year & $\begin{array}{c}\text { Farmland } \\
\text { (jin } \\
\text { unhusked } \\
\text { rice) }\end{array}$ & Rooms & $\begin{array}{c}\text { Number } \\
\text { of sons }\end{array}$ & $\begin{array}{c}\text { Average } \\
\text { Farmland } \\
\text { (jin } \\
\text { unhusked } \\
\text { rice) }\end{array}$ & $\begin{array}{c}\text { Average } \\
\text { Number } \\
\text { of } \\
\text { Rooms }\end{array}$ \\
\hline 1 & Que Shengzong & 1751 & 10140 & 10 & 3 & 3380 & 3.3 \\
\hline 2 & Que Qixing & 1762 & 8242 & 7 & 4 & 2060.5 & 1.75 \\
\hline 3 & Que Tiangui & 1814 & 68387 & 12 & 4 & 17091.75 & 3 \\
\hline 4 & Que Decong & 1838 & 53209 & 28 & 4 & 13302.25 & 7 \\
\hline 5 & Que Hanchen & 1862 & 16679 & 7 & 3 & 5559.66 & 2.33 \\
\hline 6 & Que Yukuan & 1902 & 13780 & 6 & 3 & 4056 & 2 \\
\hline
\end{tabular}

\begin{tabular}{|c|l|c|c|c|c|c|c|}
\hline $\begin{array}{c}\text { Number of } \\
\text { Generation }\end{array}$ & Name & Year & $\begin{array}{c}\text { Farmland } \\
\text { (jin } \\
\text { unhusked } \\
\text { rice) }\end{array}$ & Rooms & $\begin{array}{c}\text { Number } \\
\text { of Sons }\end{array}$ & $\begin{array}{c}\text { Average } \\
\text { Farmland } \\
\text { (jin } \\
\text { unhusked } \\
\text { rice) }\end{array}$ & $\begin{array}{c}\text { Average } \\
\text { Number } \\
\text { of } \\
\text { Rooms }\end{array}$ \\
\hline 1 & Que Shengzong & 1751 & 10140 & 10 & 3 & 3380 & 3.3 \\
\hline 2 & Que Qixing & 1762 & 8242 & 7 & 4 & 2060.5 & 1.75 \\
\hline 3 & Que Tiangui & 1814 & 68387 & 12 & 4 & 17091.75 & 3 \\
\hline 4 & Que Deyao & 1839 & 46150 & 21 & 5 & 9230 & 4.2 \\
\hline 5 & Que Hanzhou & 1873 & 11999 & 4 & 3 & 3999.66 & 1.33 \\
\hline
\end{tabular}


Appendix 2 Household Property of several consecutive generations of the Ye

\section{Family}

\begin{tabular}{|c|l|c|c|c|c|c|c|}
\hline $\begin{array}{c}\text { Number of } \\
\text { Generation }\end{array}$ & Name & Year & $\begin{array}{c}\text { Farmland } \\
(\mathrm{mu})\end{array}$ & Rooms & $\begin{array}{c}\text { Number } \\
\text { of sons }\end{array}$ & $\begin{array}{c}\text { Average } \\
\text { Farmland } \\
(\mathrm{mu})\end{array}$ & $\begin{array}{c}\text { Average } \\
\text { Number } \\
\text { of } \\
\text { Rooms }\end{array}$ \\
\hline 1 & Ye Yilin & 1790 & 20.1 & 5 & 5 & 4.02 & 1 \\
\hline 2 & Ye Chengmei & 1831 & 57.2 & 12 & 2 & 8.6 & 6 \\
\hline 3 & Ye Biao & 1852 & 27.6 & 7 & 3 & 9.2 & 2.33 \\
\hline 4 & Ye Weijia & 1863 & 4.5 & 8 & 0 & $\begin{array}{c}\text { Inherited by his two } \\
\text { brothers }\end{array}$ \\
\hline
\end{tabular}

\section{Appendix 3 Sources of all collected Fenjiashu}

\begin{tabular}{|c|c|c|c|}
\hline Place & Year & $\begin{array}{l}\text { Family } \\
\text { name }\end{array}$ & Source \\
\hline Anhui & 1732 & Feng & $\begin{array}{l}\text { Wang, Zhenzhong. (2006) Qingdai Yige Huizhou } \\
\text { Xiaonong Jiating de Shenghuo Zhuangkuang [Life of A } \\
\text { Peasant Family in Huizhou in Qing Dynasty].Journal of } \\
\text { Shanghai Normal University, 35: 101-9. }\end{array}$ \\
\hline \multirow[t]{21}{*}{ Zhejiang } & 1906 & $\mathrm{Fu}$ & unpublished source \\
\hline & 1845 & Que & \multirow{20}{*}{$\begin{array}{l}\text { Cao, Shuji et al. eds. (2015) Shicang Qiyue [Collection } \\
\text { of Civil Contracts from Shicang] (Hangzhou: Zhejiang } \\
\text { University Press) vol. 8, issue 4; vol. 7, issue 4; vol. 6, } \\
\text { issue 4; vol. 5, issue 4; vol. 5, issue 3. }\end{array}$} \\
\hline & 1746 & Que & \\
\hline & 1749 & Que & \\
\hline & 1858 & Que & \\
\hline & 1883 & Que & \\
\hline & 1858 & Que & \\
\hline & 1766 & Que & \\
\hline & 1740 & Que & \\
\hline & 1750 & Que & \\
\hline & 1769 & Que & \\
\hline & 1792 & Que & \\
\hline & 1814 & Que & \\
\hline & 1814 & Que & \\
\hline & 1817 & Que & \\
\hline & 1820 & Que & \\
\hline & 1836 & Que & \\
\hline & 1855 & Que & \\
\hline & 1851 & Que & \\
\hline & 1838 & Que & \\
\hline & 1814 & Que & \\
\hline
\end{tabular}




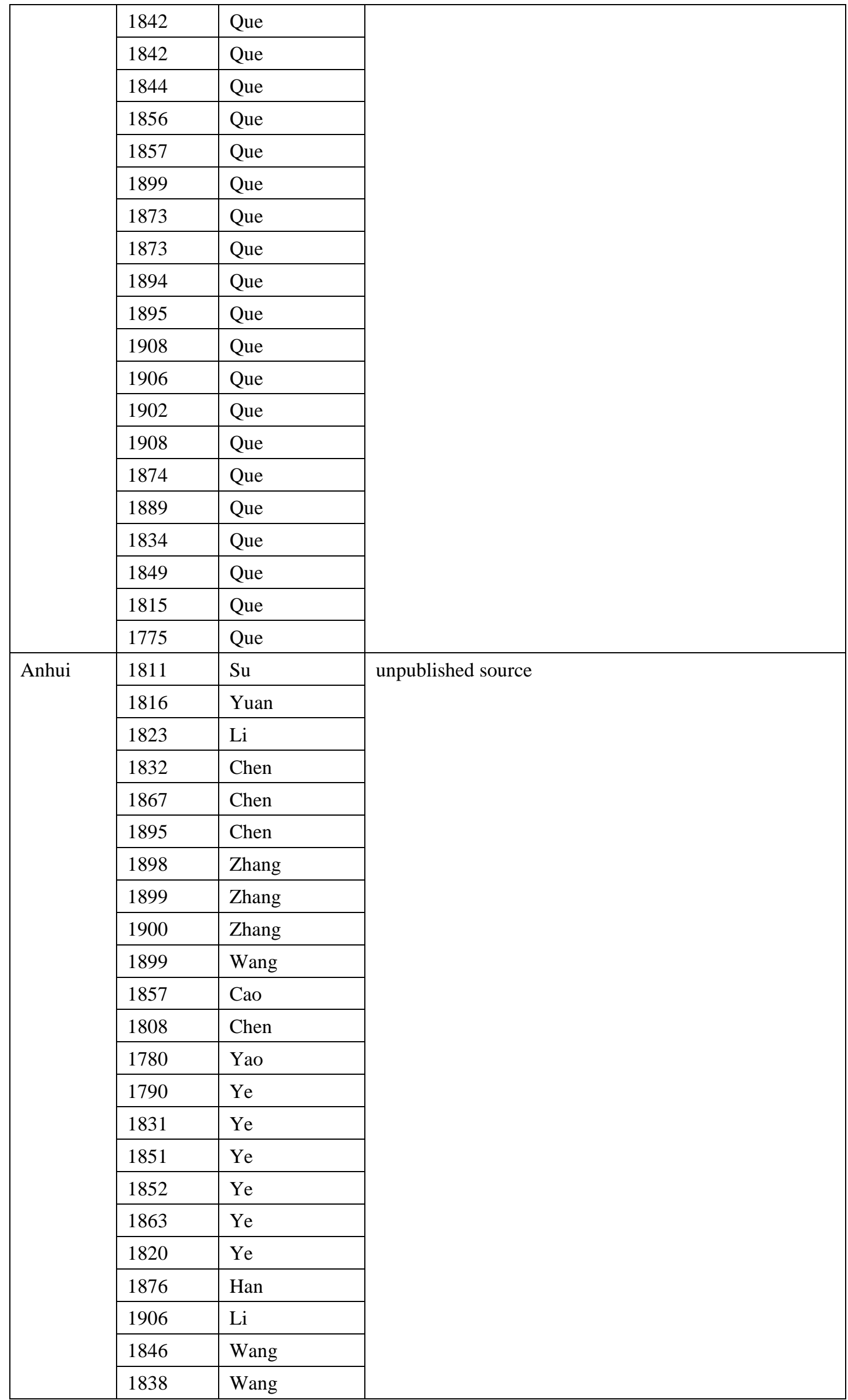




\begin{tabular}{|c|c|c|c|}
\hline & 1848 & Zheng & \\
\hline & 1906 & Zong & \\
\hline \multirow[t]{18}{*}{ Shanxi } & 1682 & Lin & \multirow[t]{14}{*}{ unpublished source } \\
\hline & 1823 & Lin & \\
\hline & 1844 & Wang & \\
\hline & 1877 & Wang & \\
\hline & 1867 & Wang & \\
\hline & 1897 & Feng & \\
\hline & 1903 & Tian & \\
\hline & 1908 & $\mathrm{Ma}$ & \\
\hline & 1905 & $\mathrm{Ma}$ & \\
\hline & 1910 & Shi & \\
\hline & 1818 & Cheng & \\
\hline & 1836 & Wang & \\
\hline & 1880 & $\mathrm{Du}$ & \\
\hline & 1906 & $\mathrm{Du}$ & \\
\hline & 1857 & Wang & \multirow[b]{2}{*}{$\begin{array}{l}\text { Hao, Ping. (2017) Wanqing Minguo Qingxuxian } \\
\text { Wangshi Jiazu Fenjia Xichan Chutan [An Analysis on } \\
\text { Separation Documents of Wang's Family in Qingxu, } \\
\text { Shanxi in the Late Qing Dynasty and Early Republic of } \\
\text { China]. Journal of Tsinghua University (Philosophy } \\
\text { and Social Sciences), 32: 79-89. }\end{array}$} \\
\hline & 1868 & Wang & \\
\hline & 1899 & $\mathrm{Ma}$ & \multirow{2}{*}{ unpublished source } \\
\hline & 1823 & $\mathrm{Lu}$ & \\
\hline \multirow[t]{8}{*}{ Anhui } & 1822 & Huang & \multirow{8}{*}{$\begin{array}{l}\text { Wang, Yuxin and Zhou Shaoquan eds.(1993) Huizhou } \\
\text { Qiannian Qiyue Wenshu:Qingdai Minguo Juan [Civil } \\
\text { Contracts from Huizhou during the Past } 1000 \text { Years: } \\
\text { Qing and Republican China] (Huashan Wenyi } \\
\text { Chubanshe) vol. 2, 3, 8, } 9 \text {. }\end{array}$} \\
\hline & 1797 & Huang & \\
\hline & 1863 & Rong & \\
\hline & 1795 & $\mathrm{Hu}$ & \\
\hline & 1825 & Huang & \\
\hline & 1894 & Zhao & \\
\hline & 1876 & Yang & \\
\hline & 1904 & Zha & \\
\hline
\end{tabular}




\section{Appendix 4 An example of Fenjiashu from Anhui}

The two sons of the creator of this division contract Widow Yao, née Wang, the eldest Zhoude and the second Zhouduo are now married and have their own children. As I am now too old to control family affairs, I am willing to divide all household property into two equal portions and give them to Zhoude and Zhouduo, except for 11.6 Mu farmland support for myself. In addition, each of the two sons should give me 2 Liang per year as a support. All houses and lands are listed as the following:

I use 1.5 rooms on the north side. 3 rooms on the west side of the inner house are given to Zhoude. 2.5 rooms on the west side of the outer house are given to Zhouduo. 3 rooms on the south side are allocated to Zhoude. 5 rooms on the south side are allocated to Zhouduo. The room outside the door including the foundation belong to Zhoude.

$7.96 \mathrm{Mu}$ farmland nearby the well is yanglao property for use in the continued support of my daily expenditures. Another $3.63 \mathrm{Mu}$ farmland is also yanglao property, but the cultivation rights is shared by Zhouduo and Zhoude equally. Every year each of them should hand over 2 Shi wheat, 1 Shi unhusked rice and 2 Dou beans to me. Two pieces of flat land at Luixiang with the area of $1.753 \mathrm{Mu}$ and 2.1 Mu respectively belong to Zhoude. 3.1 Mu slopes on the southeast side is given to Zhoude. Two pieces of slopes on the south side of our village with the area of 5.77 Mu and 3.6 Mu respectively are also given to Zhoude. 2.2 Mu Pawned land and 1.8 Mu graveyard are equally shared by Zhoude and Zhouduo. Three pieces of slopes on the south side of our village with the area of $3.67 \mathrm{Mu}, 4.13 \mathrm{Mu}$, and 1.575 Mu respectively are given to Zhouduo. 3.3 Mu slopes on the southwest side is given to Zhouduo. 2.1Mu flat land at Luixiang belong to Zhouduo. Two pieces of flat land on the south side of our village with the area of $1.9375 \mathrm{Mand} 2.175 \mathrm{Mu}$ are also given to Zhouduo.

Witness: Wang Defang, Yao Weixiao

Sep.26, $45^{\text {th }}$ Year of Qianlong's Reign, the creator of this division contract Widow Yao, née Wang

\section{References}

Buck, John L. (1937) Land Utilization in China (Nanking).

Cao, Shuji. (2001) Zhongguo Renkoushi [ Population History of China](Shanghai: Fudan University Press) vol. 5.

Cao, Shuji. et al. eds. (2015) Shicang Qiyue [Collection of Civil Contracts from Shicang](Hangzhou: Zhejiang University Press) vol. 6, issue 4.

Dai, Yi. (1980) Jianming Qingshi [ A Brief History of the Qing](Beijing: Renmin Publishing House) vol.1.

Fei, Hsiao-Tung. (1986) Jiangcun Jingji [Peasant Life in China: A Field Study of Country Life in the Yangtze Valley] (Nanjing: Jiangsu Renmin Press). 
Finnane, Antonia. (2017) Furnishing the home in Qing Yangzhou: A case for rethinking "consumer constraint”. In: Elif Akcetin and Suraiya Faroqhi, eds. Consumption in the Qing and Ottoman Empires of the Eighteenth Century (The Hague and Boston: Brill), pp. 163-86.

Flinn, Midchal W. (1981) The European Demographic System 1500-1800 (The Harvester Press).

Foster, A. and Rosenzweig, Mark R. (2002) Household division and rural economic growth. Review of Economic Studies, 69: 839-69.

Freedman, Maurice. (1979) The Study of Chinese Society: Essays (Stanford University Press).

Houlbrooke, Ralph A. (1984) The English Family, 1450-1700 (London, New York: Longman).

Howell, C. (1978) Peasant Inheritance Customs in the Midlands 1280-1700. In: J. Goody, ed. Family and Inheritance (Cambridge Press), pp.141-42.

Huang, Philip C. C. (1992) Changjiang Sanjiaozhou de Xiaonong Jiating yu Xiangcun Fazhan[The Peasant Family and Rural Development in the Yangzi Delta, 1350-1988] (Zhonghua Book Company).

Huang, Philip C. C. (2000) Huabei de Xiaonong Jingji yu Shehui Bianqian [The Peasant Economy and Social Change in North China] (Zhonghua Book Company).

Liang, Shumin. (1990) Liang Shumin Quanji [Collected Works of Liang Shuming] (Jinan: Shandong People's Publishing House) vol. 2; vol. 3.

Luo, Lun and Jing, Su. (1985), Qingdai Shandong Jingying Dizhu Jingji Yanjiu [A Study of Commercial Landlord Economy in Shandong Province in Qing Dynasty] (Jinan: Qilu Shushe).

Maddison, Augus. (1998) Chinese Economic Performance in the Long Run (Paris: Development Center of the Organization for Economic Co-operation and Development).

Man, Yongqian. (1988) Zhongxi Jichengzhi de Bijiao Yanjiu [A comparative study between Chinese and Western inheritance systems]. World History, 3: 1-11.

Myers, Ramon H. (1999) Zhongguo Nongmin Jingji: Hebei he Shandong de Nongye Fazhan, 18901949 [The Chinese Peasant Economy: Agricultural Development in Hepei and Shandong 18901949] (Nanjing, Jiangsu People's Publishing House).

Perkins, Dwight H. (1984) Zhongguo Nongye de Fazhan [Agricultural Development in China 13681968] (Shanghai: Shanghai Yiwen Press).

Schuurman, A. (1980) Probate inventories: Research issues, problems and results. AAG Bijdragen, 23: $19-33$. 
Seccombe, G. Waly. (1992) A Millennium of Family Change-Feudalism to Capitalism in Northwestern Europe (London: Verso).

Schleifer, A. (2000) Inefficient markets: An introduction o behavioral finance (Oxford: Oxford University Press).

Shi, Zhihong. (2018) Agricultural Development in Qing China: A Quantitative Study, 1661-1911 (The Hague and Boston: Brill).

Thaler, R. H. (2015) Misbehaving: The making of behavioral economics (New York: Norton).

Wakefield, David. (1998) Fenjia: Household Division and Republican China (University of Hawaii Press).

Wang, Yuesheng. (2002) An analysis of marriage during the mid-Qing Dynasty. Historical Research, 6: $44-55$.

Williamson, J. (2000) Real Wages and Factor Prices Around the Mediterranean 1500-1940. In: S. Pamuk and J. G. Williamson, eds. The Mediterranean Response to Globalization Before 1950 (London: Routledge), pp. 45-75.

Wu, Chengming. (2001) Zhongguo de Xiandaihua: Shichang yu Shehui [China's modernization: The Market and the Society] (Beijing, SDX Joint Publishing Company).

Wu, Jen-shu and Wang, Dagang. (2017) A preliminary study of local consumption in the Qianlong Reign (1736-1796): The case of Ba County in Sichuan Province. In: Elif Akcetin \& Suraiya Faroqhi, eds. Consumption in the Qing and Ottoman Empires of the Eighteenth Century ( The Hague and Boston: Brill), pp. 196-203.

Xing, Tie. (1995) Woguo Gudai de Zhuzi Pingjun Xichan Wenti [Equal household division in ancient China]. Chinese History Research, 4: 3-15.

Xu, Y., Shi, Z., van Leeuwen, B., Ni, Y., Zhang, Z. and Ma, Y. (2017) Chinese national income, ca. 1661-1933. Australian Economic History Review, 57(3): 368, 393.

Xu, Y., van Leeuwen, B. and van Zanden, J. L. (2018) Urbanization in China, ca. 1100-1900. Frontiers of Economics in China, 13 (3): 322-68.

Zhang, Yan. (2010) Qingdai Shehui Jingjishi Yanjiu [Social and Economic History Research of Qing Dynasty] (Beijing: Beijing Normal University Press).

Zhang, Youyi. (1988) Benshiji Ersanshi Niandai Woguo Diquan Fenpei Zaiguji [Re-estimation of land distribution in 1920-1930s]. The Journal of Chinese Social and Economic History, 2: 3-10. 
Zhao, Gang. (2005) Zhongguo Chuantong Nongcun Diquan Fenpei [Countryside Land Distribution in Traditional China] (Taipei: Linking Publishing Company).

Zheng, Zhenman. (2009) Mingqing Fujian Jiazu Zuzhi yu Shehui Bianqian [Linage Organizations and Social Changes in Fujian during the Ming and the Qing] (Beijing, China Renmin University Press). 